Archived version from NCDOCKS Institutional Repository http://libres.uncg.edu/ir/asu/

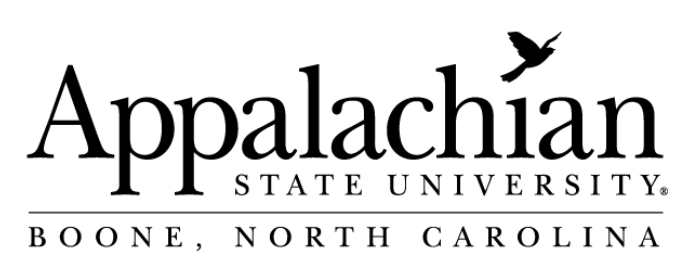

\title{
Measuring the Benefits of Mentoring for Foster Grandparents: A Research Note
}

\author{
Author: Kenneth Muir
}

\begin{abstract}
The impact of intergenerational mentoring between retirees and first-year college has largely been ignored in gerontological research. This research note explores the methodology of designing a mentoring pro-gram that targets "foster grandparents" and first-year college students using life satisfaction scales.
\end{abstract}

Kenneth Muir (2006) "Measuring the Benefits of Mentoring for Foster Grandparents: A Research Note" Educational Gerontology vol.32 pp.379-387 Version of Record Available @(DOI: 10.1080/03601270600564138) 


\title{
MEASURING THE BENEFITS OF MENTORING FOR FOSTER GRANDPARENTS: A RESEARCH NOTE
}

\author{
Kenneth B. Muir \\ Department of Sociology and Social Work, Appalachian State University, \\ Boone, North Carolina, USA \\ The impact of intergenerational mentoring between retirees and first- \\ year college has largely been ignored in gerontological research. This \\ research note explores the methodology of designing a mentoring pro- \\ gram that targets "foster grandparents" and first-year college students \\ using life satisfaction scales.
}

\section{INTRODUCTION}

Most retirees desire to remain active, both physically and mentally. However, "atrophy of opportunity" as Atchley (2000) has called it, too often intervenes-resulting in a mismatch between a desire to remain active and a social need for experienced mentors. According to the AARP (1993), volunteer work and mentoring continues to consume more time in the older population than for any other age group. While mentoring of at-risk and minority populations has attracted the interest of researchers during recent years, the benefits of older adults mentoring college students is an area of gerontology that has been-with a few notable exceptions-largely overlooked.

With the older population of the United States expected to increase to nearly 90 million by the year 2050 (U.S. Bureau of the Census, 2002), the means by which members of the older population keep active, is an area of research that should hold the interest of gerontologists and sociologists alike. The results of intergenerational mentoring programs suggest several mutually beneficial results for both 
the mentors and those who are being mentored (Manheimer, 1997; Generations United, 2002). As Manheimer notes:

A number of purposes and benefits have been advanced for intergenerational education, including: to encourage young and old to overcome prejudices and stereotypes held by the other group; to build common bonds between generations as they discover shared life themes, challenges and problems; (and) to gain new conceptual frames of reference and multigenerational perspectives on a wide variety of historical topics and social issues (Manheimer, 1997, pp. 81).

In addition, according to a 2002 Generations United report, benefits for older mentors include a "more productive lifestyle that contributes to a greater sense of purpose and allows (older mentors) to feel more connected to their communities." The report also suggests that retired people look to remain connected to their communities and gain a sense of interconnectedness when involved in programs. In fact, according to the Generations United report, more than 85\% of adults surveyed report plans to commit to community service and volunteer work. The benefits for mentored youth include decreased drug use, decreased alcohol use and abuse, better school attendance rates, and better relationships with family members.

Much of the research dealing with the effects of intergenerational mentoring has explored the impact of the mentoring process on select groups (Bradley, Peacock, \& Shenk, 2001; Dansky, 1996; Rogers \& Taylor, 1997; Bedient, Snyder, \& Simon, 1992; Brown, Davis, \& McClendon, 1999; Fagan \& Fagan, 1983). The University of Nebraska-Omaha's Intergenerational Mentoring Project, for example, matched students studying to become teachers with retired faculty members affiliated with Omaha schools (Nebraska State Education Association, 2004). In addition, at Southern Illinois University at Carbondale, retired faculty members are teamed with 1 st year special admissions students. These at-risk students meet on a regular basis with faculty mentor teams to ensure a smooth transition by the students into academic life. The program, begun in 1989, has shown promising results for the at-risk students

The mentors, having spent much of their careers on the campus, bring to their task a history of service to and experience with the university.... Their own vast experience qualifies them to advise students not only about academic matters but also about their problems with roommates, instructors, parents, and other students (Bedient et al., 1992, pp. 463). 
The program results at Southern Illinois University at Carbondale also suggest positive outcomes for students. Those enrolled in the program attend class on a more regular basis, complete more assignments, and are more interested in doing well in their university= college experience compared to those students not participating in the program (Bedient et al., 1992).

While studies examining the relationship between mentoring and intergenerational experiences between older people and young people remains an active area of research, much of this research is in the field of social work and gerontological education (Freedman, 1993; Rogers \& Taylor, 1997). Research dealing with at-risk youth suggests a positive correlation between intergenerational mentoring and the young person's academic success (Bernier, Larose, \& Soucy, 2005; Bullard \& Felder, 2003; Ziege, 2000). The bulk of the research in academic mentoring focuses on the impact of mentoring on minority and poor youth in primary and secondary grades. However, little is known about the potentially positive benefits of mentoring on college students. A sampling of community programs nationwide include programs such as the Senior Corps' Foster Grandparent Program; the Eldernet Education Committee; the Brookdale Center on Aging of Hunter College (NY); Rainbow Bridge's Family and Elders Program; and Youth and Elders Program. These programs suggest college-age students are not given the same level of attention by mentors as are at-risk or minority student populations.

While the findings of these studies suggest positive results for specifically targeted groups, many colleges and universities look for means of retaining general populations of students in addition to those identified as at risk. For example, in 1993, Appalachian State University began what would become a highly successful freshman seminar program. The program is designed to create a learning community by linking 1 st year students with a freshman seminar course and one other course designed for 1st year students such as introduction to sociology, introduction to psychology, world civilizations, or American literature. Oneinstructorin the freshman seminar course is linked with an instructor in another course, and the two plan a course of study for the students. The 1st year students who participate in the program have shown higher 1 year retention rates than those students not participating in the program (Henscheid, 2004). One-year retention rates-defined as those students who return to the university upon completion of their first year of studies-averaged approximately 5.1\% to $6.4 \%$ higher for those students in the Freshman Seminar program during a 5 year period. In all, during the past 5 years of the Freshman Learning Community, the average retention rate was $89.1 \%$ compared to the entire 
freshman class average retention rate of $83.3 \%$ (Office of Institutional Research,Appalachian State University, 2002, 2004, \& 2005).

\section{DESIGN OF THE STUDY}

Research on the effects of mentoring and volunteer work on the wellbeing of the older population in the United States is broad and wide ranging. For the aging population, however, much of the research focuses on mentoring older people in the workforce (see, for example, Goldberg, 2000; Zemke, 2000). Other research examines entrance into a retired lifestyle and the transition many older adults have to make (Kerschner, 1995). Andrews and Robinson (1991) note three areas of research emerging in recent years: mental health, quality of life, and social gerontology. With many studies examining subjective well-being across a wide range of variables, the reliability of research measures is very high (Robinson, Shaver, \& Wrightsman, 1991).

Life satisfaction scales, in combination with geriatric depression scales, are seen as one means of measuring the impact of mentoring on older persons' well-being. As noted earlier, research suggests the benefits of mentoring for the mentor include improved mental health, improved physical health, and a longer, better quality of life (Ziege, 2000).

\section{SET UP OF THE PILOT PROGRAM}

Both Time magazine and US News and World Report have named Appalachian State University's Freshman Learning Program as an example of a mentoring=service-learning program designed to increase retention rates of 1 st year students. The program engages participants from in-coming 1 st year students who register for the learning community. Students are paired with an instructor in a freshman seminar program and an instructor in, among others, introductory sociology, introductory psychology, or freshman composition classes. The typical class size for a learning community is 25 students. Paired with two instructors, the students then meet either twice or three times weekly with each instructor. Additionally, an important component of the learning community is a service-learning project. The primary objective of the program, therefore, is to create a sense of community among the students wherein they have a safe haven - or fall back position-in which they may freely discuss problems associated with joining a university community, such as managing class assignments. As noted earlier, research concerning 1 st year-student retention rates suggests students participating in 
the program continue on to their 2 nd year of college at higher rates than those students not participating in the freshman learning communities. In addition to the higher retention rates, students participating in the learning community program also tended to have higher grade-point averages (GPA) than nonparticipating students (Henscheid, 2004).

While 1st year-student retention rates were higher among those students participating in the freshman learning community, the involvement of mentors - such as foster grandparents-is seen as a possible factor in increasing the retention rate over the duration of the students' college career, not just for the year following initial enrollment.

For the purpose of this pilot study-tentatively planned for implementation fall 2006 - two Freshman Learning Communities of 25 will be randomly assigned to experimental and control groups. Both groups of 25 will plan to meet weekly with the freshmanseminar instructor and the introduction-to-sociology instructor. After the 25 experimental-group students are selected, a compatibility test will be administered to determine which students (mentees) will be assigned to the designated mentors. Foster grandparents will be recruited from Appalachian Senior Programs-a northwestern North Carolina agency that includes Foster Grandparent Program (FGP) and Senior Companion Program (SCP). A state-run agency, Appalachian Senior Programs recruits volunteers from a 5 county region. The more than 50 retirees currently in the Foster Grandparent Program and Senior Companion Program are compensated volunteers. Because of the scope of the Senior Companion Program, only volunteers from the Foster Grandparent Program will be recruited to participate in this study. Mentor=mentee assignments will be based on an informal compatibility survey administered to each volunteer foster grandparent and the members of the control and experimental groups (see the Appendix).

Weekly informal meetings with the foster grandparent mentors and the members of the experimental groups will be held on campus. Foster grandparent mentors will also be provided with computers and computer access to campus Internet so they can communicate with their mentees. The mentors will be asked to attend class twice monthly or more, depending on their interest and availability. The foster grandparent mentors also will be provided with a course textbook and study guide materials.

Several factors are important in the selection of a scale to measure life satisfaction or well being (Robinson et al., 1991). As the authors note, subjective well-being is a complex concept, and there 
exists no consensus on the best means to go about measuring it. Differences between measuring scales also may yield unreliable results.

(t)he fine-grained differences among subjective well-being measures in relative quality tend not to be well replicated from one psychometric assessment to another. This is at least partly attributable to reviewers using different combinations of subjective well-being measures, different types of respondents, and different assessment criteria. It is also probably attributable to the fact that the better scales ... do not differ radically in measurement quality: All are pretty good; none seem markedly better than the others (Robinson et al., 1991, p. 109).

Because of these concerns, a Life Satisfaction Index scale was selected (Neugarten, Havighurst, \& Tobin, 1961). The scale was selected due to the open-ended nature of the questions asked of respondents. Some modifications in the wording were made, as suggested by the authors. In addition, as the authors report, the scale was tested on a number of older adults with a high degree of reliability. The scale also was tested on younger adults, with a lower degree of reliability reported. This may be due, in part, to the researchers not conducting a test-retest. For the purpose of this pilot study, a pretest=posttest administration of the Life Satisfaction Index will be completed.

\section{Life Satisfaction Index}

The following questions comprise the Life Satisfaction Index that will be administered in this pilot study:

1. What are the best things about being the age you are now?

2. What do you think you will be doing 3 years from now?

3. How do you think things in your life will be different in the next few years from the way they are now?

4. What is the most important thing in your life right now?

5. How happy would you say you are right now, compared with earlier periods in your life?

6. Do you ever worry about your ability to do what people expect of you - that is, to meet the demands that people make on you?

7. If you could do anything you wanted to, in what part of the United States would you like to live?

8. How often do you find yourself feeling lonely? 
9. Do you wish you could see more of your close friends than you do, or would you like more time to yourself?

10. How much unhappiness would you say you find in your life today?

11. As you get older, would you say things seem to be better or worse than you thought they would be?

12. How satisfied would you say you are with your life?

13. As you look at your life accomplishments, are you happy with what you have done?

Robinson et al. (1991) also offer several considerations for selection of scales and pretest=posttest application of the scales. In addition to theoretical implications of scale selection, the authors also suggest researchers consider the available financial resources, amount of time available to interview subjects, the degree of precision (statistical validity and significance), and whether the results will be compared with existing research dealing with well-being. Finally, since this is a pilot study with no previous results existing for the population under study, the considerations outlined by Robinson et al., are not seen as necessarily critical to the expected outcome of the research. They could, however, prove to be crucial for future research.

\section{REFERENCES}

AARP. (1993). Older workforce: Recruitment and retention: A survey. AARP Workforce Programs Dept. report.

Andrews, F. M. \& Robinson, J. P. (1991). Measures of subjective well-being. In J. P. Robinson, P. R. Shaver, \& L. S. Wrightsman (Ed.), Measures of personality and social psychological attitudes. New York: Academic Press.

Atchley, R. C. (2000). Social forces and aging: An introduction to social gerontology. Belmont, CA: Wadsworth.

Bedient, D., Snyder, V., \& Simon, M. C. (1992). Retirees mentoring at-risk college students. Phi Beta Kappan, 73(6), 462 - 464.

Bernier, A., Larose, S., \& Soucy, N. (2005). Academic mentoring in college: The interactive role of student' $\mathrm{s}$ and mentor' $\mathrm{s}$ interpersonal dispositions. Research in Higher Education, 46(1), 29 - 52.

Bradley, D. B., Peacock, J. R., \& Shenk, D. (2001). Mentoring between and within generations of gerontology students. Gerontology and Geriatrics Education, 22(2), $1-14$.

Brown, M. C., Davis, G. L., \& McClendon, S. (1999). Mentoring graduate students of color: Myths, models, and modes. Peabody Journal of Education, 74(2), 105 - 118.

Bullard, L. G. \& Felder, R. M. (2003). Mentoring. College Teaching, 51(2), 66 - 70.

Dansky, K. H. (1996). The effect of group mentoring on career outcomes. Group and Organizational Management, 21(1), 5 - 17. 
Fagan, M. M. \& Fagan, P. D. (1983). Mentoring among nurses. Nursing and Health Care, $4,80-82$.

Freedman, L. (1993). The kindness of strangers: Adult mentors, urban youth and the new voluntarism. San Francisco, CA: Jossey-Bass.

Generations United. (2002). Intergenerational mentoring: A unique response to the challenges of youth (Fact sheet). Generations United. Reprinted with permission of Generations United (http:=www.gu.org).

Goldberg, B. (2000). Age works: What Corporate America must do to survive the graying of the workforce. New York: Free Press.

Henscheid, J. M. (2004). Integrating the first-year experience: The role of first-year seminars in learning communities. National resource center for the first-year experience \& students in transition. Columbia, SC: University of South Carolina Press.

Kerschner, H. (1995). Think productivity for oldest residents. Provider, 21(12), $69-70$.

Manheimer, R. J. (1997). Generations living together. Journal of Gerontological Social Work, $28(1-2), 79-91$.

Nebraska State Education Association (NSEA). (2004). Making matches: NSEA pilots mentoring project coupling teachers in training with retirees. NSEA Voice. Retrived March 2004, from www.NSEA.org.

Neugarten, B. L., Havighurst, R. J., \& Tobin, S. S. (1961). The measurement of life satisfaction. Journal of Gerontology, 16, 134 - 143.

Office of Institutional Research, Appalachian State University. (2002). Freshman seminar annual report to the chancellor, 2001 - 2002. Appalachian State University annual report. Boone, NC: Office of Institutional Research, Appalachian State University.

Office of Institutional Research, Appalachian State University. (2004). Freshman seminar retention report. Appalachian State University annual report. Boone, NC: Office of Institutional Research, Appalachian State University.

Office of Institutional Research, Appalachian State University. (2005). Freshman seminar retention report. Appalachian State University annual report. Boone, NC: Office of Institutional Research, Appalachian State University.

Robinson, J. P., Shaver, P. R., \& Wrightsman, L. S. (1991). Measures of personality and social psychological attitudes. New York: Academic Press.

Rogers, A. \& Taylor, A. (1997). Intergenerational mentoring: A viable strategy for meeting the needs of vulnerable youth. Journal of Gerontological Social Work, $28(1-2), 125-140$.

U.S. Bureau of the Census. (2002). Statistical abstract of the United States. Washington, DC: U.S. Government Printing Office.

Zemke, R., Raines, C., Filipczak, B. (2000). Generations at work: Managing the clash of veterans, boomers, Xers, and nexters in your workplace. New York: Amacom.

Ziege, A. (2000). The effects of mentor status characteristics on relationship outcomes in a program for minority undergraduates. Unpublished doctoral dissertation. Madison, WI: University of Wisconsin at Madison. 


\section{APPENDIX}

\section{Compatibility Survey}

\section{Circle one response for each statement}

1. I like to study or work alone.

Disagree Somewhat disagree Don' tknow Somewhat agree Agree

2. I consider myself to be an outgoing person.

Disagree Somewhat disagree Don' tknow Somewhat agree Agree

3. I consider myself to be a religious person.

Disagree Somewhat disagree Don' tknow Somewhat agree Agree

4. I like to be actively involved in extracurricular activities or sports.

Disagree Somewhat disagree Don' tknow Somewhat agree Agree

5. I prefer to listen to music by myself in a quiet environment.

Disagree Somewhat disagree Don' tknow Somewhat agree Agree

6. I consider myself a neat person.

Disagree Somewhat disagree Don' tknow Somewhat agree Agree

7. I enjoy studying and learning new things.

Disagree Somewhat disagree Don' tknow Somewhat agree Agree

8. I am open to different lifestyles and attitudes.

Disagree Somewhat disagree Don' tknow Somewhat agree Agree

9. I enjoy solving problems.

Disagree Somewhat disagree Don' tknow Somewhat agree Agree

10. I enjoy reading and relaxing more than sports.

Disagree Somewhat disagree Don' tknow Somewhat agree Agree

